\title{
Citrus Flavanone Narirutin, In Vitro and In Silico Mechanistic Antidiabetic Potential
}

\author{
Ashraf Ahmed Qurtam ${ }^{1,+}{ }^{\text {, Hamza Mechchate }}{ }^{2,+} \mathbb{D}$, Imane Es-safi ${ }^{2, *} \mathbb{D}$, Mohammed Al-zharani ${ }^{1}$, Fahd A. Nasr $^{3} \mathbb{D}$, \\ Omar M. Noman ${ }^{3}{ }^{D}$, Mohammed Aleissa ${ }^{1}$, Hamada Imtara ${ }^{4} \mathbb{D}_{\text {, }}$ Abdulmalik M. Aleissa ${ }^{5}$, Mohamed Bouhrim ${ }^{6} \mathbb{D}^{\circ}$ \\ and Ali S. Alqahtani ${ }^{3}$ D
}

1 Biology Department, College of Science, Imam Mohammad Ibn Saud Islamic University (IMSIU), Riyadh 11623, Saudi Arabia; AAQURTAM@imamu.edu.sa (A.A.Q.); MMyAlzahrani@imamu.edu.sa (M.A.-z.); msaleissa@imamu.edu.sa (M.A.)

2 Laboratory of Biotechnology, Environment, Agrifood and Health, Faculty of Sciences Dhar El Mahraz, University of Sidi Mohamed Ben Abdellah, Fez 30000, Morocco; Hamza.mechchate@usmba.ac.ma

3 Department of Pharmacognosy, College of Pharmacy, King Saud University, Riyadh 11451, Saudi Arabia; fnasr@ksu.edu.sa (F.A.N.); onoman@ksu.edu.sa (O.M.N.); alalqahtani@ksu.edu.sa (A.S.A.)

4 Faculty of Arts and Sciences, Arab American University Palestine, Jenin 240, Palestine; Hamada.tarayrah@gmail.com

5 King Khaled Eye Specialist Hospital (KKESH), Riyadh 11462, Saudi Arabia; aaleissa@kkesh.med.sa

6 Laboratory of Bioresources, Biotechnology, Ethnopharmacology and Health, Faculty of Sciences, Mohammed First University, Oujda B.P. 717, Morocco; mohamed.bouhrim@gmail.com

Citation: Qurtam, A.A.; Mechchate, H.; Es-safi, I.; Al-zharani, M.; Nasr, F.A.; Noman, O.M.; Aleissa, M.; Imtara, H.; Aleissa, A.M.; Bouhrim, M.; et al. Citrus Flavanone Narirutin, In Vitro and In Silico Mechanistic Antidiabetic Potential. Pharmaceutics 2021, 13, 1818. https://doi.org/ 10.3390/pharmaceutics13111818

Academic Editors: Diana

Marcela Aragon Novoa and Fátima Regina Mena Barreto Silva

Received: 9 September 2021

Accepted: 21 October 2021

Published: 31 October 2021

Publisher's Note: MDPI stays neutral with regard to jurisdictional claims in published maps and institutional affiliations.

Copyright: (C) 2021 by the authors. Licensee MDPI, Basel, Switzerland. This article is an open access article distributed under the terms and conditions of the Creative Commons Attribution (CC BY) license (https:// creativecommons.org/licenses/by/ $4.0 /)$.
* Correspondence: Imane.essafi1@usmba.ac.ma

+ These authors contributed equally to this work.

\begin{abstract}
Citrus fruits and juices have been studied extensively for their potential involvement in the prevention of various diseases. Flavanones, the characteristic polyphenols of citrus species, are the primarily compounds responsible for these studied health benefits. Using in silico and in vitro methods, we are exploring the possible antidiabetic action of narirutin, a flavanone family member. The goal of the in silico research was to anticipate how narirutin would interact with eight distinct receptors implicated in diabetes control and complications, namely, dipeptidyl-peptidase 4 (DPP4), protein tyrosine phosphatase 1B (PTP1B), free fatty acid receptor 1 (FFAR1), aldose reductase (AldR), glycogen phosphorylase (GP), alpha-amylase (AAM), peroxisome proliferator-activated receptor gamma (PPAR- $\gamma$ ), alpha-glucosidase (AGL), while the in vitro study looked into narirutin's possible inhibitory impact on alpha-amylase and alpha-glucosidase. The results indicate that the studied citrus flavanone interacted remarkably with most of the receptors and had an excellent inhibitory activity during the in vitro tests suggesting its potent role among the different constituent of the citrus compounds in the management of diabetes and also its complications.
\end{abstract}

Keywords: narirutin; naringenin rutinoside; isonaringin; molecular docking; mechanism of action; enzyme; receptors

\section{Introduction}

Diabetes is a severe, long-term disease that has a significant effect on the lives and well-being of people, families, and communities all over the globe. It is among the top ten causes of mortality in adults, with an estimated four million fatalities worldwide in 2017 [1]. The International Diabetes Federation (IDF) has been tracking diabetes on national, regional, and worldwide scales since 2000. In 2009, 285 million individuals were projected to have diabetes (including T1D and T2D), 366 million in 2011, 382 million in 2013, 415 million in 2015, 425 million in 2017, 463 million in 2019 and the global projection is 578 million by 2030, and 700 million by 2045 [1-5]. Diabetes has a tremendous social cost in terms of increased medical expenses, lost productivity, early death, and intangible costs such as decreased quality of life. Diabetes cost the global health system 727 billion USD 
in 2017 [1]. Furthermore, changes in the demography of the diabetic community, healthcare use and delivery patterns, technology, medical expenses, insurance coverage, and economic circumstances continue to have an impact on the economic burden of diabetes [6]. While several synthetic oral medicines have been established to treat diabetes, it is still a struggle to control diabetes without any side effects [7]. A new surge of scientific interest in conventional practices has been stimulated by increased research about complementary drugs and natural therapies, and the desire to look for more powerful agents with less side effects [8-11]. It is commonly known that low intake of unhealthy foods, daily physical exercise and strong consumption of plant-based products help to maintain a stable state of health [12]. In fact, an elevated dietary amount of fruit and vegetables is correlated with a decreased risk of some life-threatening diseases, such as cardiovascular disease and cancer [13]. Many phenolic secondary metabolites (flavonoids) found in plant-derived foods are now increasingly recognized to have beneficial health effects on the prevention and treatment of diseases $[14,15]$. Flavonoids are plant secondary metabolites belonging to polyphenolic family, and constitute a very interesting and important class of natural products commonly present in fruits, vegetables and some beverages [16]. They are an essential component of a variety of nutraceuticals, pharmaceutical, medicinal and cosmetic uses due to their broad spectrum of health-promoting properties $[17,18]$. This is due to their ability to regulate critical cellular enzyme activities, as well as their antioxidative, anti-inflammatory, antimutagenic, and anticarcinogenic characteristics $[19,20]$. They are phenolic chemicals of low molecular weight and one of the most distinctive groups of chemicals found in higher plants.

Flavanones, which are found in all citrus fruits such as oranges, lemons and grapes, are one of the most significant subgroups of flavonoids [21,22]. Because of their free radical-scavenging characteristics, they are linked to a variety of health advantages. Citrus fruit juice and peel contain these chemicals, which give them a bitter flavor. Citrus flavonoids have pharmacological actions against reactive oxygen species, inflammation, and are involved in lowering blood lipids and cholesterol [23]. Different studies have investigated their role (i.e., luteolin, apigenin) in epigenetic therapy and cell gene expression by regulating HDAC1, HDAC2 [24] and MMP-2 [25].

In this study, we looked into the antidiabetic potential of narirutin (flavanone-7O-glycoside), a flavanone family representative, consisting of the flavanone naringenin bonded with the disaccharide rutinose (Figure 1), through different approaches to assess its mechanistic proprieties as a preventive and curative natural alternative. Molecular docking was used to evaluate molecular interaction with the following receptors: dipeptidylpeptidase 4 (DPP4), protein tyrosine phosphatase 1B (PTP1B), free fatty acid receptor 1 (FFAR1), aldose reductase (AldR), glycogen phosphorylase (GP), alpha-amylase (AAM), peroxisome proliferator-activated receptor gamma (PPAR- $\gamma$ ), and alpha-glucosidase (AGL). The alpha-amylase and alpha-glucosidase enzymes were tested in vitro to see whether the compound has any inhibitory action.

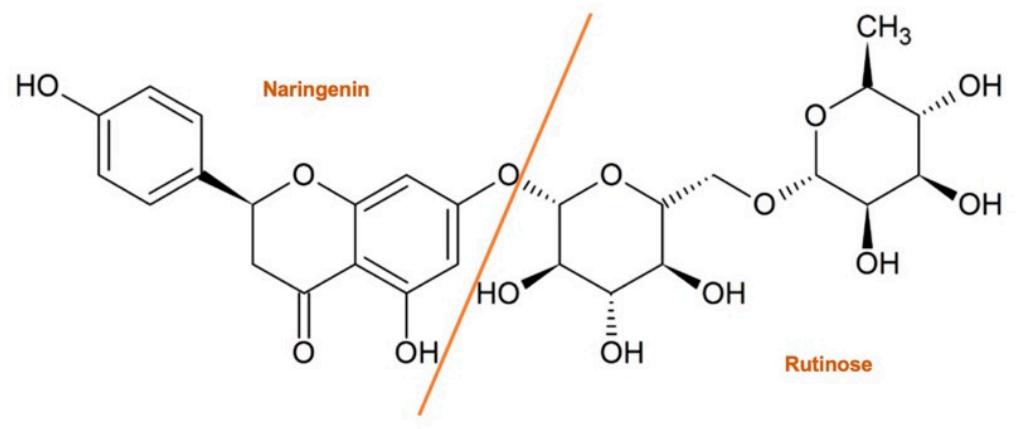

Flavanone-7-O-glycoside / Narirutin

Figure 1. Narirutin chemical structure, formula and molar mass. 


\section{Results and Discussion}

\subsection{Molecular Docking}

To confirm the interaction of the receptor with the ligand, literature screening was performed to identify the active site of the receptor and the amino acids composing it. Table 1 shows the result of the in silico simulation of the studied molecule and the selected receptors (affinity), the active site description and the amino acids that interact with a hydrogen bond in the site.

Table 1. Summary of narirutin/receptors affinities.

\begin{tabular}{|c|c|c|c|c|}
\hline Receptor & $\begin{array}{c}\text { Affinity } \\
\text { (kcal/mol) }\end{array}$ & Active Site Described in Literature & $\begin{array}{l}\text { Interaction } \\
\text { Confirmed with } \\
\text { the Active Site }\end{array}$ & H-Bonds \\
\hline PTP1B & -8.5 & $\begin{array}{c}\text { Trp179, Pro180, Asp181 [26], His214, Ser216, } \\
\text { Ala217, Gly218, Ile219, Gly220, and } \\
\text { Arg221 [27,28] and the active site on Cys } \\
215 \text { (catalytic loop) }\end{array}$ & Yes & $\begin{array}{c}\text { Arg221, } \\
\text { Arg24, Ser216 }\end{array}$ \\
\hline DPP4 & -10.4 & $\begin{array}{l}\text { DPP } 4 \text { active site ( } \alpha / \beta \text {-hydrolase domain) is } \\
\text { identified by the residues from } 39 \text { to } 51 \text { and } \\
\text { from } 501 \text { to } 706[29,30] \text {. }\end{array}$ & Yes & $\begin{array}{l}\text { Tyr662, Ser209, } \\
\text { Ser630, Arg125, } \\
\text { His740, Trp629, }\end{array}$ \\
\hline FFAR1 & -8.3 & $\begin{array}{c}\text { Active site includes Arg183, Arg258 and } \\
\text { Tyr2240 [31]. Binding pocket is on Glu172, } \\
\text { Arg183, Ser187, Tyr240, Asn241, Asn244, } \\
\text { Arg258 and Tyr91 [32,33]. }\end{array}$ & Yes & Tyr44 \\
\hline Alpha amylase & -9.9 & $\begin{array}{l}\text { Active site:Asp197, Glu233 and Asp300 and } \\
\text { other important AA: Arg337, Arg195, } \\
\text { Asn298, Phe265, Phe295, His201, Ala307, } \\
\text { Gly306, Trp203, Trp284, Trp59, Tyr62, Trp58, } \\
\text { His299 and His101 [34-37]. }\end{array}$ & Yes & $\begin{array}{l}\text { Gly306, Asp197, } \\
\text { Gln63, Trp69, } \\
\text { Lys352, Asp352 }\end{array}$ \\
\hline PPAR gamma & - & $\begin{array}{l}\text { PPAR } \gamma \text { ligand-binding domain: Ser289, } \\
\text { His323, Tyr473, and His449 [38]. }\end{array}$ & No & \\
\hline $\begin{array}{l}\text { Alpha } \\
\text { glucosidase }\end{array}$ & -8.7 & $\begin{array}{l}\text { The amino acids involved in the } \\
\text { a-Glucosidase activity are Asp404, Asp518, } \\
\text { Arg600, Asp616, and His674 Trp376, Ile441, } \\
\text { Trp516, Met519, Trp613, and Phe649 Leu405, } \\
\text { Trp481, Asp645, and Arg672 [39,40]. }\end{array}$ & Yes & $\begin{array}{l}\text { Asp616, Ala284, } \\
\text { Arg281, } \\
\text { Asp282, Ser523 }\end{array}$ \\
\hline $\begin{array}{l}\text { Aldose } \\
\text { reductase }\end{array}$ & -9.3 & $\begin{array}{l}\text { The active site is located in the barrel core } \\
\text { clearly seen in the } 3 \mathrm{D} \text { structure [41] }\end{array}$ & Yes & $\begin{array}{l}\text { Val47, Gln49, } \\
\text { Lys21, Ser32 }\end{array}$ \\
\hline $\begin{array}{c}\text { Glycogen } \\
\text { phosphorylase }\end{array}$ & -8.3 & $\begin{array}{l}\text { Active site on amino acids } 280-288 \text { (The } \\
\qquad 280^{\prime} \text { s loop) }[42,43] .\end{array}$ & Yes & $\begin{array}{c}\text { Asp283, } \\
\text { Glu382, leu384 }\end{array}$ \\
\hline
\end{tabular}

\subsubsection{PTP1B}

Resistance to insulin's cellular action, a basic pathophysiological flaw associated with the global obesity pandemic, is linked to the development of type 2 diabetes and metabolic syndrome, a collection of cardiovascular risk factors. The discovery of new pharmacological medicines that help alleviate insulin resistance may be crucial not only for the prevention and treatment of diabetes but also for lowering the cardiovascular risk profile associated with it $[44,45]$.

Although that PTP1B direct action to control the cardiovascular function is still unclear, there is more evidence linking this receptor with the inhibition of the regulation of metabolic function and cardiovascular function because of its direct interaction with various receptor tyrosine kinase signaling pathways [46]. Overall, these investigations have opened the way for the commercialization of PTP1B inhibitors, which may be used as a new kind 
of "insulin sensitizer" in the treatment of type 2 diabetes and cardiovascular/metabolic syndromes [47].

Figure 2 shows that narirutin had a strong contact with the catalytic site and the active site, with a docking affinity of $8.5 \mathrm{kcal} / \mathrm{mol}$ and three hydrogen bonds formed.
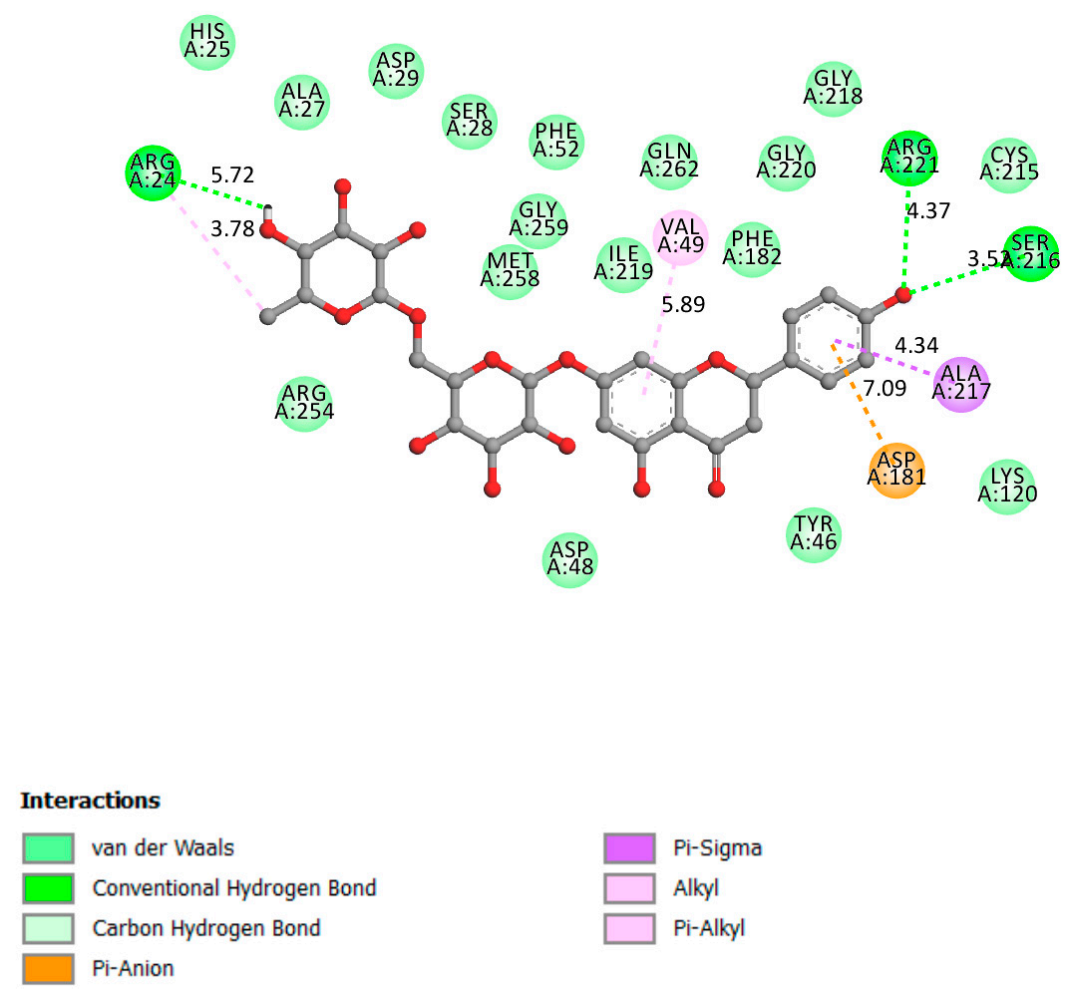

Figure 2. Two-dimensional scheme of the narirutin interactions with PTP1B.

\subsubsection{DPP4}

DPP4 inhibitors have been linked to better blood glucose management and lower fasting and postprandial blood glucose levels while avoiding weight gain [48]. DPP4 inhibition by a chemotherapeutic agent may raise the levels of circulating endogenous GLP-1 by prolonging its half-life, thus increasing GLP-1's beneficial effects in glucosedependent insulin production and cell restoration. DPP-4 belongs to the serine protease family, which also includes the fibroblast activation protein (FAP), DPP-8, and DPP-9 [49]. DPP-4 inhibitors provide many benefits, including a reduced risk of hypoglycemia, minimal weight gain, and the possibility for pancreatic -cell repair and separation [50].

In the $\alpha / \beta$-hydrolase domain, excellent interactions were established between narirutin and DPP4 receptor, with a docking affinity of $10.4 \mathrm{kcal} / \mathrm{mol}$ and 6 hydrogen bonds formed, as shown in Figure 3.

\subsubsection{FFAR1}

Free fatty acid receptor 1 (FFAR1) agonists have recently been discovered as a promising anti-diabetic target, since they regulate secretion stimulated by glucose in the pancreatic cells without causing hypoglycemia [51]. The FFAR1 mode of action is via interaction with a $\mathrm{G}$ protein. The coupling mechanism activates phospholipase-C, which regulates inositol triphosphate and the endoplasmic reticulum's release of intracellular $\mathrm{Ca}^{2+}$. As a result, insulin secretion improves in a glucose concentration-dependent manner [52].

The Docking results demonstrated good interactions between narirutin and the FFAR1 receptor (Affinity of $-8.3 \mathrm{kcal} / \mathrm{mol}$ ) with one single hydrogen bond formed (Figure 4 ). 


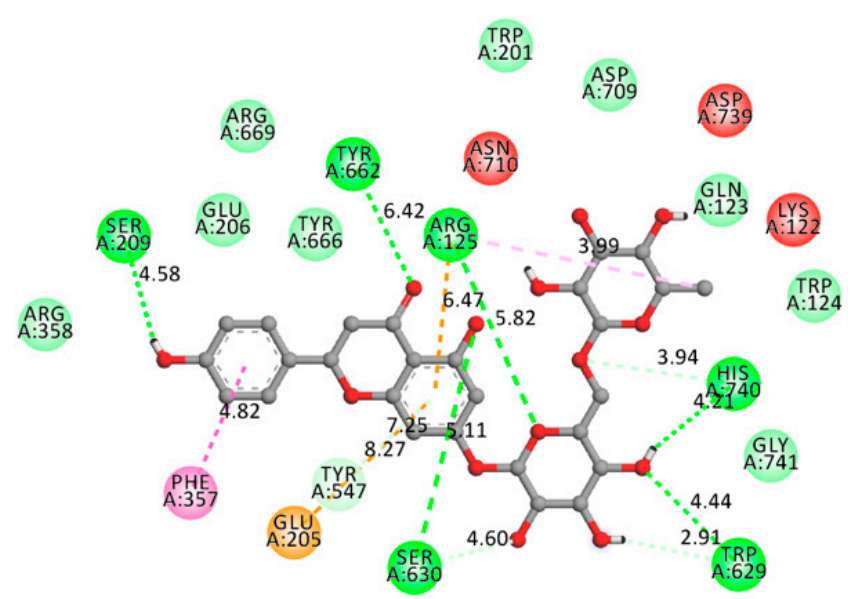

Interactions

van der Waals

Conventional Hydrogen Bond

Carbon Hydrogen Bond

Pi-Cation

Pi-Anion

Pi-Donor Hydrogen Bond

Pi-Pi Stacked

Alkyl

Figure 3. Two-dimensional scheme of the narirutin interactions with DPP4.

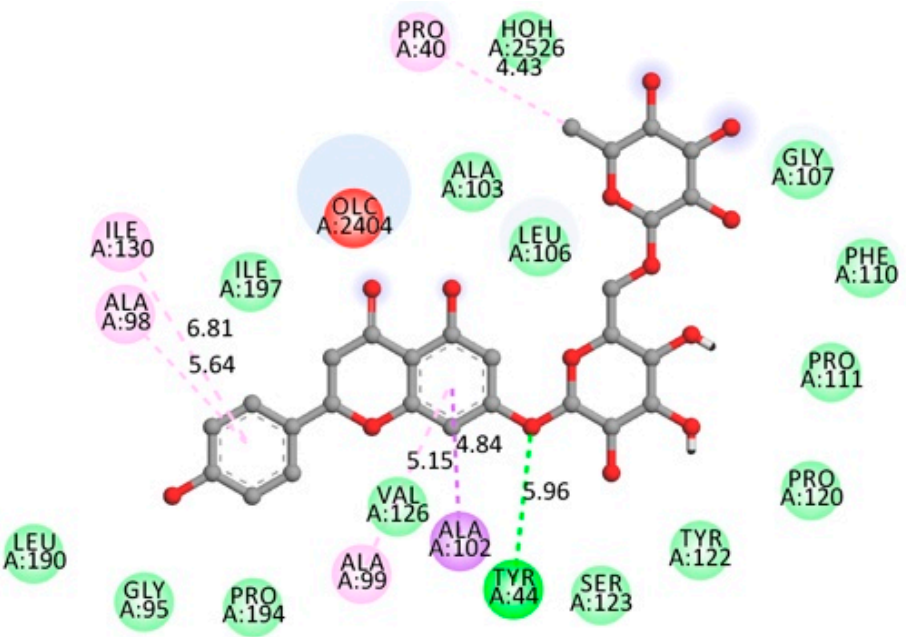

Interactions

Interactions
$\square$ van der Waals

Conventional Hydrogen Bond

Pi-Sigma

Amide-Pi Stacked

Alkyl

Pi-Alkyl

Figure 4. Two-dimensional scheme of the narirutin interactions with FFAR1.

\subsubsection{Alpha-Amylase}

Alpha-amylases are present in a broad range of living creatures (plants, animals, bacteria, and fungi). They are also present in human salivary glands, and the pancreas secretes them into the small intestine on a regular basis during digestion. They belong to the amylase family of enzymes whose main role in the body is to catalyze the hydrolysis 
of complex polysaccharides into small digestible mono, di and trisaccharide, converted afterwards to glucose as the fuel for energy production [53,54].

Figure 5 shows the interactions between narirutin with the alpha-amylase receptor on the catalytic residues (affinity of $-9.9 \mathrm{kcal} / \mathrm{mol}$ ) with the formation of six hydrogen bonds.

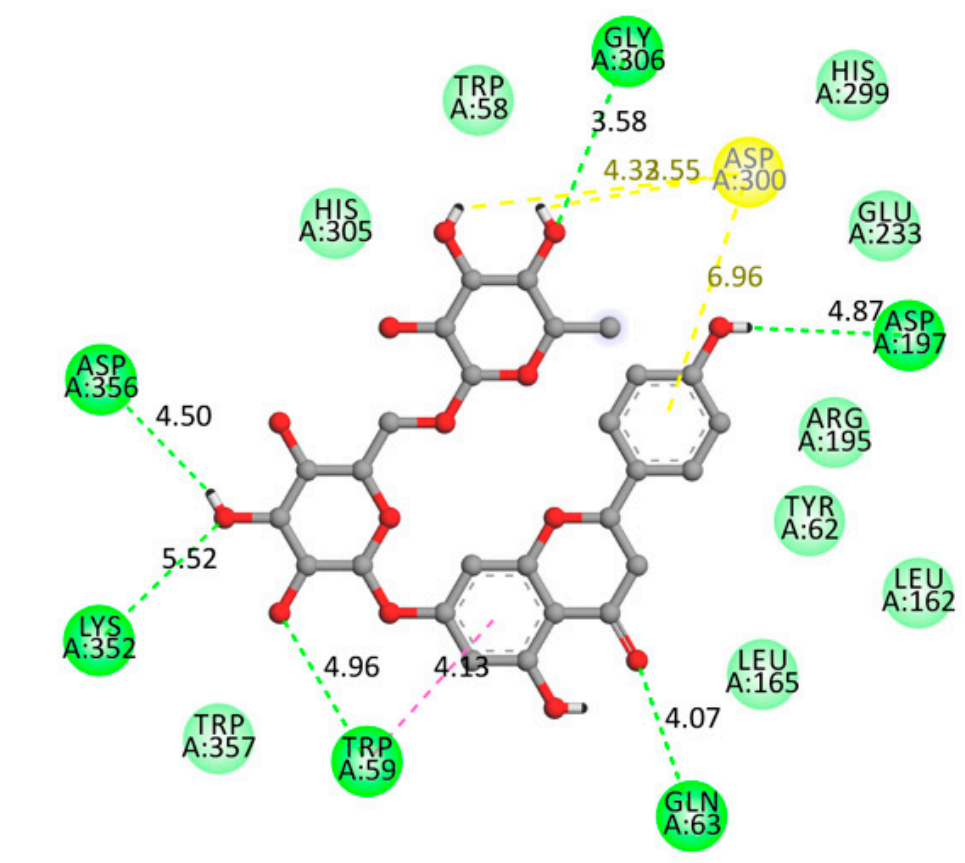

Interactions

$\square$ van der Waals

Conventional Hydrogen Bond

Figure 5. Two-dimensional scheme of the narirutin interactions with AAM.

\subsubsection{PPAR $\gamma$}

Peroxisome proliferator-activated receptor gamma (PPAR $\gamma)$ is a protein that controls gene expression and is found in key reproductive components [55]. PPARs are important regulators of cellular differentiation, cellular growth, and carbohydrate, lipid, and protein metabolism in humans. PPAR $\gamma$ has been linked to a key role in glucose homeostasis [56], making it a promising target for T2DM treatment. It is highly expressed in adipose tissue and, for optimum DNA binding and transcriptional activity, needs heterodimerization with the retinoid X-receptor (RXR) [56]. PPAR $\gamma$ stimulates the expression of glucose transporters (GLUT4) and subsequent translocation, leading to decreased levels of blood glucose, blood gluconeogenesis repression and enhanced lipide storage and glucose intake into muscles, and performs a number of psychological activities [57]. Increased insulin sensitizing effect occurs when adipose genes are activated.

Docking findings and various poses analysis revealed no established interaction between narirutin and the PPAR $\gamma$ receptor. The results were confirmed when compared with the default ligand cocrystalized with the receptor PDB format (Rosiglitazone), which binds perfectly into the receptor active site.

\subsubsection{Alpha-Glucosidase}

Alpha-glucosidase is one of the digestive enzymes, its main function is to accelerate the hydrolysis of polysaccharides (starch) to glucose (acts on (14) bonds) in order to promote glucose absorption and, therefore, raise blood glucose levels [58]. This helps to prevent hyperglycemia and maintain normal blood sugar levels by slowing down the digestion of starch and extra dietary carbohydrates [58].

Figure 6 indicates that narirutin had a good interaction with the receptor active site with 4 hydrogen bonds formed and an affinity of $-8.7 \mathrm{kcal} / \mathrm{mol}$. 

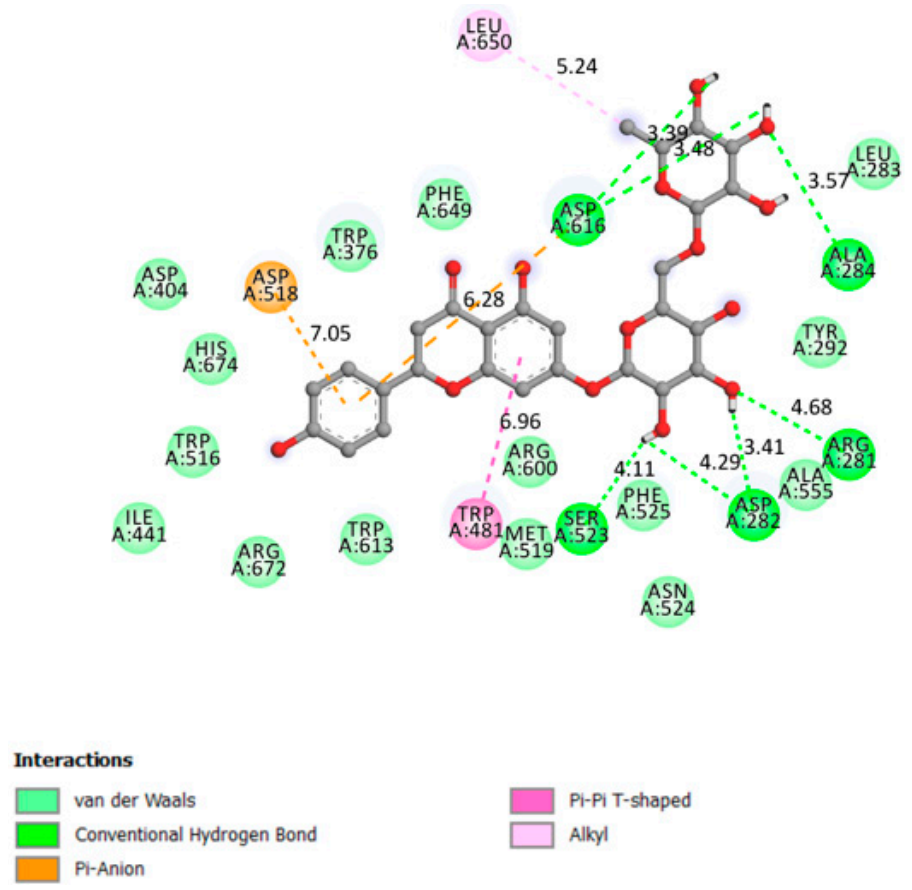

Figure 6. Two-dimensional scheme of the narirutin interactions with AGL.

\subsubsection{Aldose Reductase}

Aldose reductase is an important enzyme that catalyzes the NAD (P) H-dependent reduction of glucose to sorbitol through the sorbitol-aldose reductase pathway. It is found in numerous organs throughout the body, including red blood cells, retina, Schwann cells, and others. As a consequence of it action, intracellular reactive oxygen species (ROS) accumulate excessively in different organs [59], leading to various health complications [60]. Excessive sorbitol buildup in tissues occurs in T2DM patients with poor sorbitol penetration and metabolism, leading to DM-related problems such as cataracts and glaucoma.

As a result, aldose reductase inhibition has been proposed as a possible treatment for T2DM problems.

The interaction between narirutin and AldR demonstrated one of the best affinities $(-9.3 \mathrm{kcal} / \mathrm{mol})$ with the ligand fitting right into the receptor barrel core (active site [41]) with five hydrogen bonds formed (Figure 7).

\subsubsection{Glycogen Phosphorylase}

Glycogen phosphorylase catalyzes glycogen hydrolysis to produce glucose-1-phosphate. Allosteric effectors and reversible phosphorylation regulate the activity of GP [61]. Phosphorylation control is a widespread intracellular mechanism that regulates, controls, and participates in signal transmission [61]. The liver may store glucose as glycogen and then generate and release glucose into the bloodstream through a reverse mechanism. As a result, the liver is closely connected to glycemic regulation, and hepatic metabolism provides numerous therapeutic options in the setting of T2DM [62].

Figure 8 displays the interaction of narirutin with GP's 280's loop (active site), with an affinity of $-8.3 \mathrm{kcal} / \mathrm{mol}$ and three hydrogen bonds formed.

The excellent affinities of the receptors/ligand interactions ranged between -8.3 and $-10.4 \mathrm{kcal} / \mathrm{mol}$, and narirutin interaction with all receptors demonstrate that this molecule can act as a multitarget medicine to treat diabetes, targeting multiple receptors involved directly and indirectly in overall diabetic status. The in silico study concluded that the predicted mechanism of action exhibited by Narirutin is the inhibition of PTP1B, DPP4, AAM, AGL, AldR, GP, and the activation of FFAR1. 


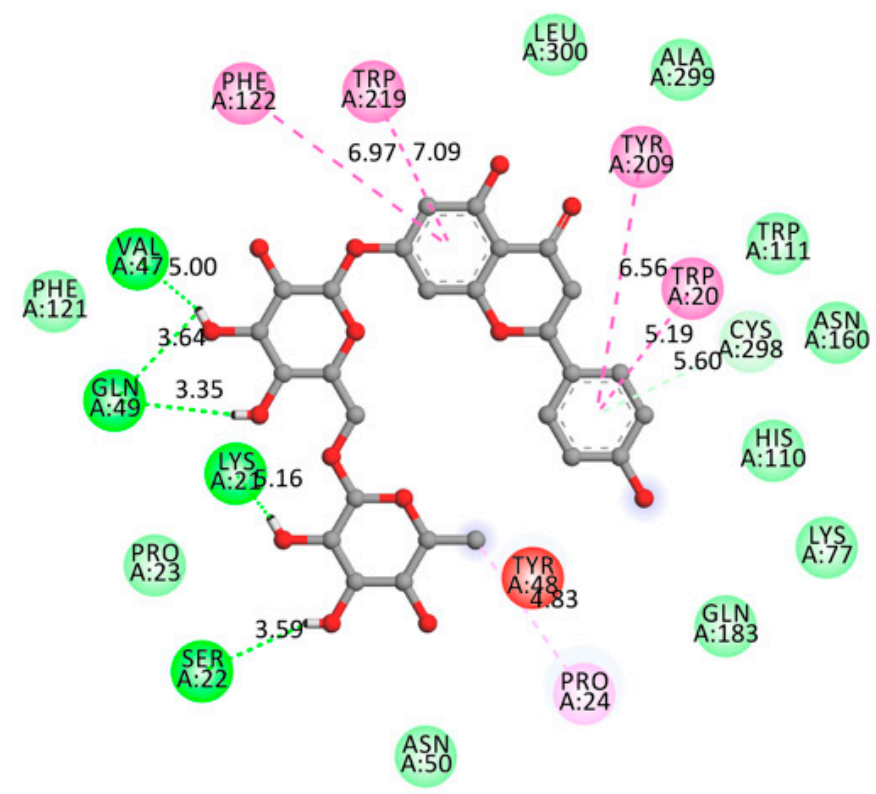

Interactions

van der Waals

Conventional Hydrogen Bond

Pi-Donor Hydrogen Bond

Pi-Pi Stacked

Pi-Pi T-shaped

Alkyl

Figure 7. Two-dimensional scheme of the narirutin interactions with AldR.

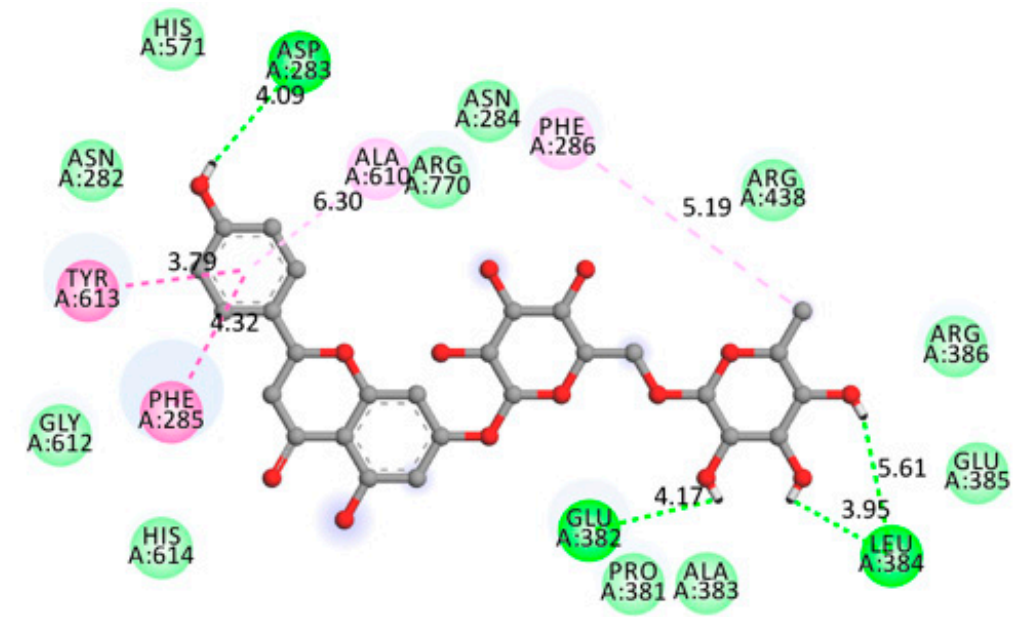

Interactions

van der Waals

Conventional Hydrogen Bond

Pi-Pi Stacked

Pi-Alkyl

Figure 8. Two-dimensional scheme of the narirutin interactions with Glycogen Phosphorylase receptor.

To have a better insight concerning the obtained results, we compared the obtained results with those obtained with other molecules such as gentisic acid [8] and amentoflavone [63] using the same methodology and against similar receptors. Gentisic acid demonstrated poor affinities ranging between -5.6 and $-6.9 \mathrm{kcal} / \mathrm{mol}$, which were partially confirmed with an in vitro investigation in which the molecule also demonstrated low activity. On the other hand, amentoflavone showed excellent affinities ranging between -8.8 and 
$-11.3 \mathrm{kcal} / \mathrm{mol}$, which was in total accordance with the molecule being well known with antidiabetic potential and tested in vivo [64].

Narirutin in vitro testing was done to partially confirm the results obtained above.

\subsection{In Vitro Assays}

One of the most effective methods for treating diabetes is to prevent glucose absorption. By blocking the digestive enzymes that hydrolyze polysaccharides into small absorbable pieces, postprandial high blood glucose is avoided. Alpha-glucosidase and alpha-amylase are two of these enzymes. The inhibitory impact of narirutin on these two enzymes were investigated to identify one or more of this plant's mechanisms of action.

\subsubsection{Alpha-Amylase Inhibitory Effect}

Alpha-amylase is considered as one of the most essential enzymes in the digestive process [34]. because of its critical involvement in the breakdown of polysaccharides. Saliva and pancreatic juice are the two most common places to find it. One approach for avoiding increasing postprandial blood glucose is to target and inhibit this enzyme [39].

Figure 9 shows the ability of narirutin to inhibit alpha-amylase. Since the concentration of narirutin obviously affects the quantity of enzyme inhibited, the inhibition of the enzyme seems to be linked to the dose. The estimated IC50 revealed that acarbose (positive control) had a lower inhibitory potential than narirutin, with an IC50 of $1.012 \mathrm{mg} / \mathrm{mL}$ for acarbose compared to $0.0066 \mathrm{mg} / \mathrm{mL}$ for narirutin. In comparison to acarbose, narirutin showed outstanding activity, which was consistent with the in silico findings.
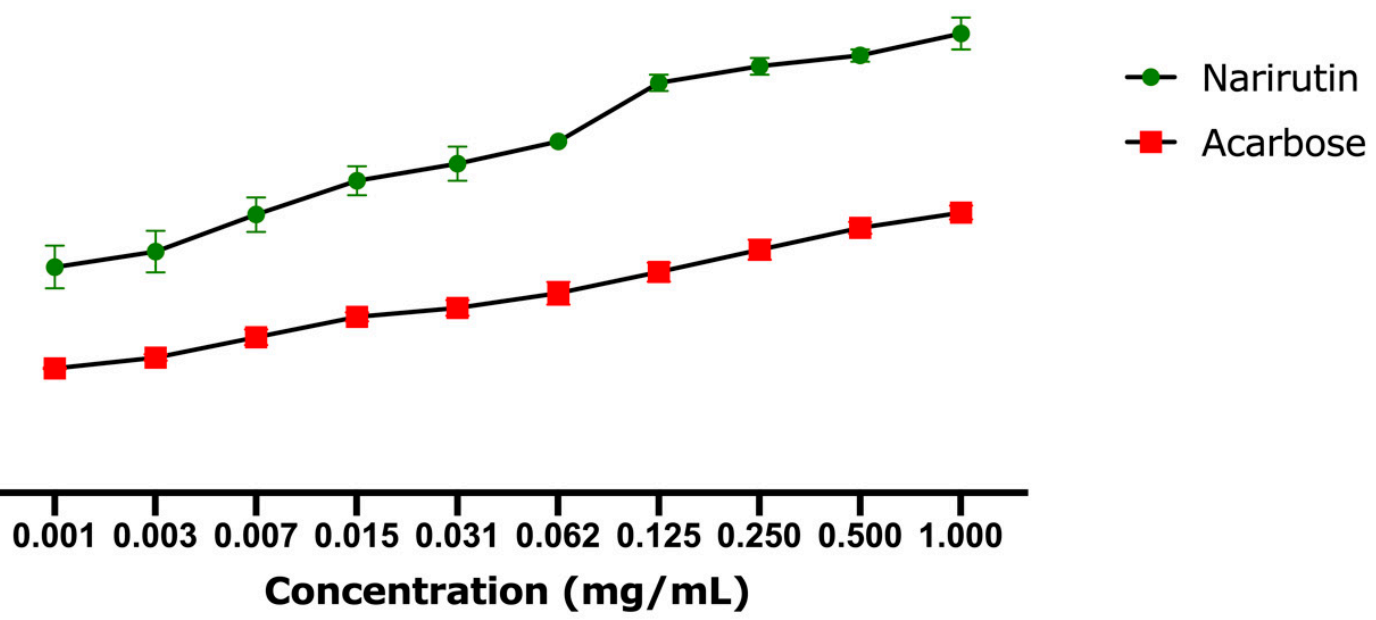

Figure 9. Alpha-amylase inhibitory effect results. Values are expressed as mean $\pm \operatorname{SD}(n=3)$.

\subsubsection{Alpha-Glucosidase Inhibitory Effect}

One of the major digesting enzymes is alpha-glucosidase, which is located in the mucosal brush border of the small intestine. Its job is to break down and convert complicated carbohydrates into short, fast, and absorbable sugars. Inhibition is a key strategy for slowing glucose absorption and avoiding high postprandial blood glucose levels, both of which may delay the onset of diabetes.

Figure 10 shows narirutin's ability to block alpha-glucosidase. The inhibitory impact is linked to the narirutin concentration since the highest concentrations showed the greatest inhibition activity. The estimated IC50 revealed that acarbose has a more powerful inhibitory action $($ IC50 $=0.00035 \mathrm{mg} / \mathrm{mL}$ ) than that observed with narirutin $(\mathrm{IC} 50=0.00091 \mathrm{mg} / \mathrm{mL})$. Nevertheless, the obtained results for narirutin are still considered powerful, and consistent with the docking findings. 


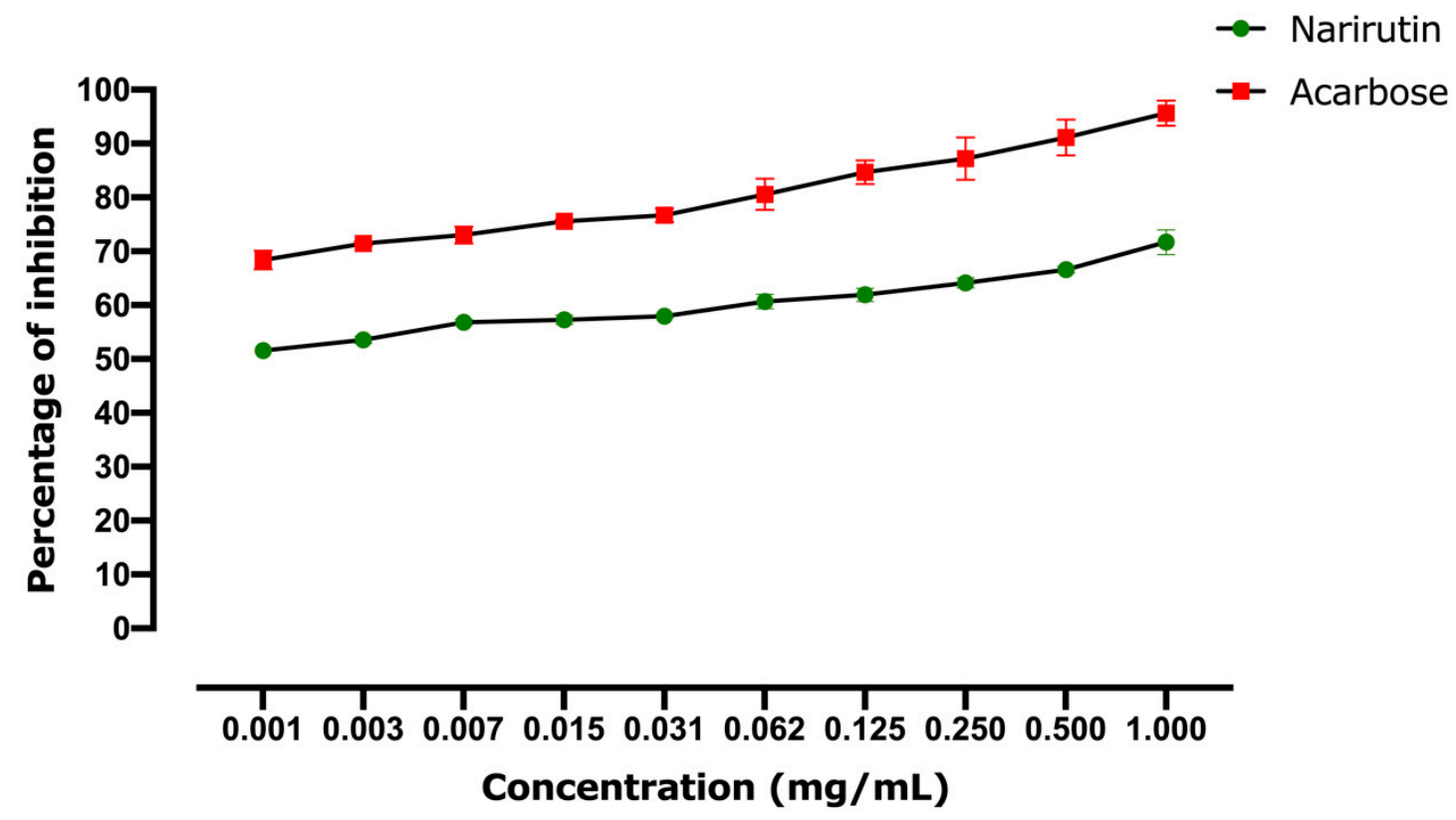

Figure 10. Alpha-glucosidase inhibitory effect results. Values are expressed as mean $\pm \mathrm{SD}(n=3)$.

As can be seen from Table 2, the results of the in vitro testing correlate perfectly with those obtained in silico. The difference in the affinity score of narirutin and acarbose against alpha-amylase in silico ( -9.9 and -8.1 respectively) was also seen in the in vitro test (0.0066 and 1.012, respectively). Against alpha-glucosidase, almost similar results were obtained in both tests, confirming the accuracy of the performed analysis.

Table 2. Summary of narirutin and acarbose in vitro and in silico activities against alpha-amylase and alpha-glucosidase.

\begin{tabular}{ccccc}
\hline & $\begin{array}{c}\text { Alpha-Amylase } \\
\text { In Vitro IC50 } \\
\text { (mg/mL) }\end{array}$ & $\begin{array}{c}\text { Alpha- } \\
\text { Glucosidase In } \\
\text { Vitro IC50 } \\
\text { (mg/mL) }\end{array}$ & $\begin{array}{c}\text { Alpha-Amylase } \\
\text { In Silico } \\
\text { Affinity } \\
\text { (kcal/mol) }\end{array}$ & $\begin{array}{c}\text { Alpha- } \\
\text { Glucosidase In } \\
\text { Silico Affinity } \\
\text { (kcal/mol) }\end{array}$ \\
\hline Narirutin & 0.0066 & 0.00091 & -9.9 & -8.7 \\
Acarbose & 1.012 & 0.00035 & -8.1 & -8.4 \\
\hline
\end{tabular}

\section{Materials and Methods}

3.1. Chemicals and Reagents

Chemicals and reagents used in this study were analytical grade (obtained from Sigma Aldrich, St. Louis, MO, USA). (Narirutin CAS: 14259-46-2; MW: 580.53, alpha-amylase CAS: 9000-85-5, alpha-glucosidase CAS: 9001-42-7).

\subsection{Molecular Docking}

\subsubsection{Preparation of the Ligand}

The SDF format of Narirutin (Figure 1) was obtained from PubChem (CID: 442431). The SDF file was converted to the PDBQT format using AutoDock Tools. For the final ligand preparation Gasteiger partial charges were added, rotatable bonds were defined and the nonpolar hydrogen atoms were merged.

\subsubsection{Preparation of the Receptors}

Each receptor's PDB file was obtained from the protein data bank website [65]. The receptors' X-ray crystal structures were selected for their completeness, resolution, and compatibility with our study goal. Details of the selected receptors are described in Table 3. 
Table 3. Selected receptors parameters.

\begin{tabular}{cccc}
\hline Receptor & PID & Resolution (Å) & Classification \\
\hline Protein tyrosine phosphatase 1B (PTP1B) & $1 \mathrm{c} 83$ & 1.80 & Hydrolase \\
Glycogen phosphorylase (GP) & $115 \mathrm{q}$ & 2.25 & Transferase \\
Free fatty acid receptor 1 (FFAR1) & $4 \mathrm{phu}$ & 2.33 & Hydrolase \\
Peroxisome proliferator-activated receptor & $5 \mathrm{ycp}$ & 2.00 & Transcription \\
gamma (PPAR gamma) & $1 \mathrm{smd}$ & 1.60 & Hydrolase \\
Alpha-amylase (AAM) & $5 \mathrm{nn} 5$ & 2.00 & Hydrolase \\
Alpha-glucosidase (AGL) & $2 \mathrm{hv} 5$ & 1.59 & Oxidoreductase \\
Aldose reductase (AR) & $2 \mathrm{p} 8 \mathrm{~s}$ & 2.20 & Hydrolase \\
\hline dipeptidyl peptidase IV (DPP4)
\end{tabular}

For the receptors, Discovery Studio Visualizer v 19.1.0 (BIOVIA, San Diego, CA, USA (windows software)) was used first to begin the preparation of the receptors before running the analysis by deleting water molecules and heteroatoms. AutoDock Tools v1.5.6 (Scripps Research, San Diego, CA, USA) were used later on to add Gasteiger charges and polar hydrogen atoms. The final file was converted to the PDBQT format to prepare for molecular docking.

\subsubsection{Simulation}

AutoDock Tools were used to establish the grid box size for each receptor, and AutoDock Vina was used to run docking simulations for the narirutin (Ligand) and the eight receptors [66]. The exhaustiveness of the simulation was set to 24. Discovery Studio Visualizer was used to visualize the protein-ligand complexes.

\subsection{Narirutin In-Vitro Inhibition Potential on Digestive Enzymes}

\subsubsection{Alpha-Amylase Inhibition Assay}

The test was carried out according to Mechchate procedure [67]. A solution of $0.2 \mathrm{~mL}$ of $0.5 \mathrm{M}$ Tris- $\mathrm{HCl}$ buffer ( $\mathrm{pH}$ 6.9) containing $0.01 \mathrm{M} \mathrm{CaCl}_{2}$ was combined with $2 \mathrm{mg}$ of starch to make the substrate solution. The substrate solution was divided into test tubes, boiled for $5 \mathrm{~min}$, and then preincubated for $5 \mathrm{~min}$ at $37^{\circ} \mathrm{C}$. Narirutin was dissolved in DMSO and produced at doses ranging from 1 to $1000 \mathrm{~g} / \mathrm{mL}$. Porcine pancreatic amylase ( $0.1 \mathrm{~mL}$ in Tris- $\mathrm{HCl}$ buffer $(2$ units $/ \mathrm{mL}$ ) was added to the test tube holding the substrate solution after the narirutin solution $(0.2 \mathrm{~mL})$ was added at various concentrations. The reaction was carried out for $10 \mathrm{~min}$ at $37^{\circ} \mathrm{C}$ before being stopped by adding $0.5 \mathrm{~mL}$ of $50 \%$ acetic acid to each test tube. The supernatant optical density was measured using a spectrophotometer at $595 \mathrm{~nm}$ after centrifugation $\left(3000 \mathrm{rpm}\right.$ for $5 \mathrm{~min}$ at $\left.4{ }^{\circ} \mathrm{C}\right)$. Acarbose was utilized as a positive control (alpha-amylase inhibitor) in this test. For each concentration, the tests were performed three times.

The inhibitory activity of alpha-amylase was determined using the formula:

$$
\text { alpha-amylase inhibitory activity }=[(A-B) / A] \times 100
$$

where the absorbance of the negative control (solution with only DMSO) is $A$, whereas that of the sample (Narirutin and acarbose) is $B$.

After evaluating the inhibitory activity of various concentrations against alpha-amylase, the IC50 values for acarbose and narirutin (concentration needed to inhibit $50 \%$ of the enzyme) were calculated.

\subsubsection{Alpha-Glucosidase Inhibitory Assay}

The test was carried out according to the procedure of Pistia Brueggeman and Hollingsworth [68]. A quantity of 50 microliters of narirutin (concentration ranging between 1-1000 g/mL) was made and incubated for $20 \mathrm{~min}$ at $37^{\circ} \mathrm{C}$ with a solution comprising 10 microliters of alpha-glucosidase $1 \mathrm{U} / \mathrm{mL}$ and $125 \mu \mathrm{L}$ of $0.1 \mathrm{M}$ phosphate 
buffer (pH 6.8) A solution of $20 \mu \mathrm{L}$ of $1 \mathrm{M}$ pNPG (substrate) was added to initiate the reaction, which was then incubated for half an hour. To stop the reaction, 50 microliters of $0.1 \mathrm{~N} \mathrm{Na}_{2} \mathrm{CO}_{3}$ were added. A spectrophotometer was used to measure the optical density at $405 \mathrm{~nm}$. Acarbose was utilized as a positive control in this test. For each concentration, the tests were performed three times.

The inhibitory activity of alpha-glucosidase was determined using the formula:

$$
\text { Alpha-glucosidase inhibitory activity }=[(A-B) / A] \times 100
$$

where the absorbance of the negative control (solution with only DMSO) is $A$, and that of the sample (Narirutin and acarbose) is $B$ After evaluating the inhibitory activity of alpha-glucosidase at various concentrations, the IC50 values for acarbose and narirutin (concentration needed to inhibit $50 \%$ of alpha-glucosidase) were calculated.

\subsection{Statistical Analysis}

Statistical analysis was performed using GraphPad prism version 7 for Windows (GraphPad Software, CA, USA). In vitro analysis was done in three replicates and presented as mean $\pm \mathrm{SD}$.

\section{Conclusions}

The antidiabetic activity of narirutin was remarkable and indicated strong and real potential by inhibition of PTP1B, DPP4, AAM, AGL, AldR, GP, and the activation of FFAR1 with excellent affinities. This conclusion was partially confirmed by in vitro tests, which confirmed the in silico results of the alpha-amylase and alpha-glucosidase experiments. The results were compared to those obtained with other antidiabetic molecules with strong and well-studied mechanism of action. This citrus flavanone deserves further standardization and complete pharmacological study to confirm its overall impact on diabetes prevention, management and also to prevent the complications.

Author Contributions: Conceptualization, A.A.Q., H.M. and I.E.-s.; methodology, M.A.-z., O.M.N and F.A.N.; software, H.M. and I.E.-s.; validation, M.A., H.I. and M.B. data curation, A.A.Q.; writingoriginal draft preparation, H.M.; writing — review and editing, A.S.A. and A.M.A.; supervision, A.S.A. All authors have read and agreed to the published version of the manuscript.

Funding: This study was funded by the Deanship of Scientific Research at Imam Mohammad Ibn Saud Islamic University for funding this work through Research Group no. RG-21-09-86.

Institutional Review Board Statement: Not applicable.

Informed Consent Statement: Not applicable.

Data Availability Statement: Data are available upon request.

Acknowledgments: The authors extend their appreciation to the Deanship of Scientific Research at Imam Mohammad Ibn Saud Islamic University for funding this work through Research Group no. RG-21-09-86.

Conflicts of Interest: The authors declare no conflict of interest.

\section{References}

1. IDF International Diabetes Federation. IDF Diabetes Atlas, 8th ed.; IDF: Brussels, Belgium, 2017.

2. International Diabetes Federation. IDF Diabetes Atlas; International Diabetes Federation: Brussels, Belgium, 2015; ISBN 978-2-930229-81-2.

3. Whiting, D.R.; Guariguata, L.; Weil, C.; Shaw, J. IDF Diabetes Atlas: Global Estimates of the Prevalence of Diabetes for 2011 and 2030. Diabetes Res. Clin. Pract. 2011, 94,311-321. [CrossRef]

4. IDF. IDF Diabetes Atlas, 6th ed.; International Diabetes Federation: Brussels, Belgium, 2013.

5. Saeedi, P.; Petersohn, I.; Salpea, P.; Malanda, B.; Karuranga, S.; Unwin, N.; Colagiuri, S.; Guariguata, L.; Motala, A.A.; Ogurtsova, K.; et al. Global and Regional Diabetes Prevalence Estimates for 2019 and Projections for 2030 and 2045: Results from the International Diabetes Federation Diabetes Atlas, 9th Edition. Diabetes Res. Clin. Pract. 2019, 157, 107843. [CrossRef] [PubMed]

6. American Diabetes Association. Economic Costs of Diabetes in the US in 2017. Diabetes Care 2018, 41, 917-928. [CrossRef] 
7. Zhou, X.; Ding, L.; Liu, J.; Su, L.; Dong, J.; Liao, L. Efficacy and Short-Term Side Effects of Sitagliptin, Vildagliptin and Saxagliptin in Chinese Diabetes: A Randomized Clinical Trial. Endocr. Connect. 2019, 8, 318-325. [CrossRef]

8. Mechchate, H.; Es-safi, I.; Mohamed Al kamaly, O.; Bousta, D. Insight into Gentisic Acid Antidiabetic Potential Using In Vitro and In Silico Approaches. Molecules 2021, 26, 1932. [CrossRef] [PubMed]

9. Khan, M.F.; Kader, F.B.; Arman, M.; Ahmed, S.; Lyzu, C.; Sakib, S.A.; Tanzil, S.M.; Zim, A.I.U.; Imran, M.A.S.; Venneri, T. Pharmacological Insights and Prediction of Lead Bioactive Isolates of Dita Bark through Experimental and Computer-Aided Mechanism. Biomed. Pharmacother. 2020, 131, 110774. [CrossRef] [PubMed]

10. Es-safi, I.; Mechchate, H.; Amaghnouje, A.; Elbouzidi, A.; Bouhrim, M.; Bencheikh, N.; Hano, C.; Bousta, D. Assessment of Antidepressant-Like, Anxiolytic Effects and Impact on Memory of Pimpinella Anisum L. Total Extract on Swiss Albino Mice. Plants 2021, 10, 1573. [CrossRef] [PubMed]

11. Iqbal, J.; Abbasi, B.A.; Ahmad, R.; Mahmoodi, M.; Munir, A.; Zahra, S.A.; Shahbaz, A.; Shaukat, M.; Kanwal, S.; Uddin, S. Phytogenic Synthesis of Nickel Oxide Nanoparticles (NiO) Using Fresh Leaves Extract of Rhamnus Triquetra (Wall.) and Investigation of Its Multiple in Vitro Biological Potentials. Biomedicines 2020, 8, 117. [CrossRef]

12. Wirnitzer, K.C. Vegan nutrition: Latest boom in health and exercise. In Therapeutic, Probiotic, and Unconventional Foods; Elsevier: Amsterdam, The Netherlands, 2018; pp. 387-453.

13. Alissa, E.M.; Ferns, G.A. Dietary Fruits and Vegetables and Cardiovascular Diseases Risk. Crit. Rev. Food Sci. Nutr. 2017, 57, 1950-1962. [CrossRef]

14. Mechchate, H.; Costa de Oliveira, R.; Es-safi, I.; Vasconcelos Mourão, E.M.; Bouhrim, M.; Kyrylchuk, A.; Soares Pontes, G.; Bousta, D.; Grafov, A. Antileukemic Activity and Molecular Docking Study of a Polyphenolic Extract from Coriander Seeds. Pharmaceuticals 2021, 14, 770. [CrossRef]

15. Al-Ishaq, R.K.; Abotaleb, M.; Kubatka, P.; Kajo, K.; Büsselberg, D. Büsselberg Flavonoids and Their Anti-Diabetic Effects: Cellular Mechanisms and Effects to Improve Blood Sugar Levels. Biomolecules 2019, 9, 430. [CrossRef] [PubMed]

16. Brodowska, K.M. Natural Flavonoids: Classification, Potential Role, and Application of Flavonoid Analogues. Eur. J. Biol. Res. 2017, 7, 108-123.

17. Ghasemzadeh, A. Flavonoids and Phenolic Acids: Role and Biochemical Activity in Plants and Human. J. Med. Plants Res. 2011, 5. [CrossRef]

18. Li, Q.; Wang, Y.; Mai, Y.; Li, H.; Wang, Z.; Xu, J.; He, X. Health Benefits of the Flavonoids from Onion: Constituents and Their Pronounced Antioxidant and Anti-Neuroinflammatory Capacities. J. Agric. Food Chem. 2020, 68, 799-807. [CrossRef]

19. Abotaleb, M.; Samuel, S.; Varghese, E.; Varghese, S.; Kubatka, P.; Liskova, A.; Büsselberg, D. Flavonoids in Cancer and Apoptosis. Cancers 2018, 11, 28. [CrossRef] [PubMed]

20. Cushnie, T.P.T.; Lamb, A.J. Antimicrobial Activity of Flavonoids. Int. J. Antimicrob. Agents 2005, 26, 343-356. [CrossRef]

21. Koolaji, N.; Shammugasamy, B.; Schindeler, A.; Dong, Q.; Dehghani, F.; Valtchev, P. Citrus Peel Flavonoids as Potential Cancer Prevention Agents. Curr. Dev. Nutr. 2020, 4, nzaa025. [CrossRef]

22. Graf, B.A.; Milbury, P.E.; Blumberg, J.B. Flavonols, Flavones, Flavanones, and Human Health: Epidemiological Evidence. J. Med. Food 2005, 8, 281-290. [CrossRef]

23. Barreca, D.; Gattuso, G.; Bellocco, E.; Calderaro, A.; Trombetta, D.; Smeriglio, A.; Laganà, G.; Daglia, M.; Meneghini, S.; Nabavi, S.M. Flavanones: Citrus Phytochemical with Health-promoting Properties. BioFactors 2017, 43, 495-506. [CrossRef] [PubMed]

24. Scafuri, B.; Bontempo, P.; Altucci, L.; De Masi, L.; Facchiano, A. Molecular Docking Simulations on Histone Deacetylases (HDAC)-1 and -2 to Investigate the Flavone Binding. Biomedicines 2020, 8, 568. [CrossRef]

25. Velmurugan, B.K.; Lin, J.-T.; Mahalakshmi, B.; Chuang, Y.-C.; Lin, C.-C.; Lo, Y.-S.; Hsieh, M.-J.; Chen, M.-K. Luteolin-7-O-Glucoside Inhibits Oral Cancer Cell Migration and Invasion by Regulating Matrix Metalloproteinase-2 Expression and Extracellular SignalRegulated Kinase Pathway. Biomolecules 2020, 10, 502. [CrossRef]

26. Jia, Z.; Barford, D.; Flint, A.; Tonks, N. Structural Basis for Phosphotyrosine Peptide Recognition by Protein Tyrosine Phosphatase 1B. Science 1995, 268, 1754-1758. [CrossRef] [PubMed]

27. Johnson, T.O.; Ermolieff, J.; Jirousek, M.R. Protein Tyrosine Phosphatase 1B Inhibitors for Diabetes. Nat. Rev. Drug Discov. 2002, 1, 696-709. [CrossRef]

28. Wiesmann, C.; Barr, K.J.; Kung, J.; Zhu, J.; Erlanson, D.A.; Shen, W.; Fahr, B.J.; Zhong, M.; Taylor, L.; Randal, M.; et al. Allosteric Inhibition of Protein Tyrosine Phosphatase 1B. Nat. Struct. Mol. Biol. 2004, 11, 730-737. [CrossRef] [PubMed]

29. Bjelke, J.R.; Christensen, J.; Branner, S.; Wagtmann, N.; Olsen, C.; Kanstrup, A.B.; Rasmussen, H.B. Tyrosine 547 Constitutes an Essential Part of the Catalytic Mechanism of Dipeptidyl Peptidase IV. J. Biol. Chem. 2004, 279, 34691-34697. [CrossRef] [PubMed]

30. Chien, C.-H.; Tsai, C.-H.; Lin, C.-H.; Chou, C.-Y.; Chen, X. Identification of Hydrophobic Residues Critical for DPP-IV Dimerization ${ }^{\dagger}$. Biochemistry 2006, 45, 7006-7012. [CrossRef]

31. Morgan, N.G.; Dhayal, S. G-Protein Coupled Receptors Mediating Long Chain Fatty Acid Signalling in the Pancreatic Beta-Cell. Biochem. Pharmacol. 2009, 78, 1419-1427. [CrossRef]

32. Sum, C.S.; Tikhonova, I.G.; Costanzi, S.; Gershengorn, M.C. Two Arginine-Glutamate Ionic Locks Near the Extracellular Surface of FFAR1 Gate Receptor Activation. J. Biol. Chem. 2009, 284, 3529-3536. [CrossRef] [PubMed]

33. Sum, C.S.; Tikhonova, I.G.; Neumann, S.; Engel, S.; Raaka, B.M.; Costanzi, S.; Gershengorn, M.C. Identification of Residues Important for Agonist Recognition and Activation in GPR40. J. Biol. Chem. 2007, 282, 29248-29255. [CrossRef] 
34. Hsiu, J.; Fischer, E.H.; Stein, E.A. Alpha-amylases as calcium-metalloenzymes. II. Calcium and the catalytic activity. Biochemistry 1964, 3, 61-66. [CrossRef] [PubMed]

35. Ragunath, C.; Manuel, S.G.A.; Venkataraman, V.; Sait, H.B.R.; Kasinathan, C.; Ramasubbu, N. Probing the Role of Aromatic Residues at the Secondary Saccharide-Binding Sites of Human Salivary $\alpha$-Amylase in Substrate Hydrolysis and Bacterial Binding J. Mol. Biol. 2008, 384, 1232-1248. [CrossRef] [PubMed]

36. Ramasubbu, N.; Ragunath, C.; Sundar, K.; Mishra, P.J.; Gyémánt, G.; Kandra, L. Structure-Function Relationships in Human Salivary $\alpha$-Amylase: Role of Aromatic Residues. Biol.-Sect. Cell. Mol. Biol. 2005, 60, 47-56.

37. Ramasubbu, N.; Ragunath, C.; Mishra, P.J.; Thomas, L.M.; Gyemant, G.; Kandra, L. Human Salivary Alpha-Amylase Trp58 Situated at Subsite -2 Is Critical for Enzyme Activity. Eur. J. Biochem. 2004, 271, 2517-2529. [CrossRef]

38. Pochetti, G.; Godio, C.; Mitro, N.; Caruso, D.; Galmozzi, A.; Scurati, S.; Loiodice, F.; Fracchiolla, G.; Tortorella, P.; Laghezza, A.; et al. Insights into the Mechanism of Partial Agonism: Crystal Structures Of The Peroxisome ProliferatorActivated Receptor $\Gamma$ Ligand-Binding Domain In The Complex With Two Enantiomeric Ligands. J. Biol. Chem. 2007, 282, 17314-17324. [CrossRef] [PubMed]

39. Alqahtani, A.S.; Hidayathulla, S.; Rehman, M.T.; ElGamal, A.A.; Al-Massarani, S.; Razmovski-Naumovski, V.; Alqahtani, M.S.; El Dib, R.A.; AlAjmi, M.F. Alpha-Amylase and Alpha-Glucosidase Enzyme Inhibition and Antioxidant Potential of 3-Oxolupenal and Katononic Acid Isolated from Nuxia Oppositifolia. Biomolecules 2019, 10, 61. [CrossRef] [PubMed]

40. Hermans, M.M.; Kroos, M.A.; van Beeumen, J.; Oostra, B.A.; Reuser, A.J. Human Lysosomal Alpha-Glucosidase. Characterization of the Catalytic Site. J. Biol. Chem. 1991, 266, 13507-13512. [CrossRef]

41. Wilson, D.K.; Bohren, K.M.; Gabbay, K.H.; Quiocho, F.A. An Unlikely Sugar Substrate Site in the 1.65 A Structure of the Human Aldose Reductase Holoenzyme Implicated in Diabetic Complications. Science 1992, 257, 81-84. [CrossRef]

42. Barford, D.; Johnson, L.N. The Allosteric Transition of Glycogen Phosphorylase. Nature 1989, 340, 609-616. [CrossRef] [PubMed]

43. Goldsmith, E.; Sprang, S.R.; Hamlin, R.; Xuong, N.; Fletterick, R. Domain Separation in the Activation of Glycogen Phosphorylase a. Science 1989, 245, 528-532. [CrossRef]

44. Elchebly, M. Increased Insulin Sensitivity and Obesity Resistance in Mice Lacking the Protein Tyrosine Phosphatase-1B Gene. Science 1999, 283, 1544-1548. [CrossRef]

45. Goldstein, B.J. Protein-Tyrosine Phosphatase 1B (PTP1B): A Novel Therapeutic Target for Type 2 Diabetes Mellitus, Obesity and Related States of Insulin Resistance. Curr. Drug Targets Immune Endocr. Metab. Disord. 2001, 1, 265-275. [CrossRef] [PubMed]

46. Ketsawatsomkron, P.; Stepp, D.W.; de Chantemèle, E.J.B. PTP1B in Obesity-Related Cardiovascular Function. In Protein Tyrosine Phosphatase Control of Metabolism; Bence, K.K., Ed.; Springer: New York, NY, USA, 2013; pp. 129-145. ISBN 978-1-4614-7855-3.

47. Zhang, Z.-Y.; Lee, S.-Y. PTP1B Inhibitors as Potential Therapeutics in the Treatment of Type 2 Diabetes and Obesity. Expert Opin. Investig. Drugs 2003, 12, 223-233. [CrossRef]

48. Matteucci, E.; Giampietro, O. Dipeptidyl Peptidase-4 (CD26): Knowing the Function before Inhibiting the Enzyme. Curr. Med. Chem. 2009, 16, 2943-2951. [CrossRef] [PubMed]

49. Kim, S.-H.; Jung, E.; Yoon, M.K.; Kwon, O.H.; Hwang, D.-M.; Kim, D.-W.; Kim, J.; Lee, S.-M.; Yim, H.J. Pharmacological Profiles of Gemigliptin (LC15-0444), a Novel Dipeptidyl Peptidase-4 Inhibitor, in Vitro and in Vivo. Eur. J. Pharmacol. 2016, 788, 54-64. [CrossRef]

50. Abd El-Karim, S.S.; Anwar, M.M.; Syam, Y.M.; Nael, M.A.; Ali, H.F.; Motaleb, M.A. Rational Design and Synthesis of New Tetralin-Sulfonamide Derivatives as Potent Anti-Diabetics and DPP-4 Inhibitors: 2D \& 3D QSAR, in Vivo Radiolabeling and Bio Distribution Studies. Bioorg. Chem. 2018, 81, 481-493. [CrossRef]

51. Ren, X.-M.; Cao, L.-Y.; Zhang, J.; Qin, W.-P.; Yang, Y.; Wan, B.; Guo, L.-H. Investigation of the Binding Interaction of Fatty Acids with Human G Protein-Coupled Receptor 40 Using a Site-Specific Fluorescence Probe by Flow Cytometry. Biochemistry 2016, 55, 1989-1996. [CrossRef]

52. Srivastava, A.; Yano, J.; Hirozane, Y.; Kefala, G.; Gruswitz, F.; Snell, G.; Lane, W.; Ivetac, A.; Aertgeerts, K.; Nguyen, J.; et al. High-Resolution Structure of the Human GPR40 Receptor Bound to Allosteric Agonist TAK-875. Nature 2014, 513, 124-127. [CrossRef] [PubMed]

53. Suvd, D.; Fujimoto, Z.; Takase, K.; Matsumura, M.; Mizuno, H. Crystal Structure of Bacillus Stearothermophilus Alpha-Amylase: Possible Factors Determining the Thermostability. J. Biochem. (Tokyo) 2001, 129, 461-468. [CrossRef]

54. Aghajari, N.; Feller, G.; Gerday, C.; Haser, R. Crystal Structures of the Psychrophilic Alpha-Amylase from Alteromonas Haloplanctis in Its Native Form and Complexed with an Inhibitor. Protein Sci. Publ. Protein Soc. 1998, 7, 564-572. [CrossRef]

55. Ahmadian, M.; Suh, J.M.; Hah, N.; Liddle, C.; Atkins, A.R.; Downes, M.; Evans, R.M. PPAR $\gamma$ Signaling and Metabolism: The Good, the Bad and the Future. Nat. Med. 2013, 19, 557-566. [CrossRef]

56. Rees, W.D.; McNeil, C.J.; Maloney, C.A. The Roles of PPARs in the Fetal Origins of Metabolic Health and Disease. PPAR Res. 2008, 2008, 1-8. [CrossRef]

57. Variya, B.C.; Bakrania, A.K.; Patel, S.S. Antidiabetic Potential of Gallic Acid from Emblica Officinalis: Improved Glucose Transporters and Insulin Sensitivity through PPAR- $\gamma$ and Akt Signaling. Phytomedicine 2020, 73, 152906. [CrossRef]

58. Attjioui, M.; Ryan, S.; Ristic, A.K.; Higgins, T.; Goñi, O.; Gibney, E.R.; Tierney, J.; O'Connell, S. Comparison of Edible Brown Algae Extracts for the Inhibition of Intestinal Carbohydrate Digestive Enzymes Involved in Glucose Release from the Diet. J. Nutr. Sci. 2021, 10, e5. [CrossRef]

59. Tang, W.H.; Martin, K.A.; Hwa, J. Aldose Reductase, Oxidative Stress, and Diabetic Mellitus. Front. Pharmacol. 2012, 3. [CrossRef] 
60. Heather, L.C.; Clarke, K. Metabolism, Hypoxia and the Diabetic Heart. J. Mol. Cell. Cardiol. 2011, 50, 598-605. [CrossRef]

61. Livanova, N.B.; Chebotareva, N.A.; Eronina, T.B.; Kurganov, B.I. Pyridoxal 5'-Phosphate as a Catalytic and Conformational Cofactor of Muscle Glycogen Phosphorylase B. Biochem. Biokhimiia 2002, 67, 1089-1098. [CrossRef]

62. Ashworth, W.B.; Davies, N.A.; Bogle, I.D.L. A Computational Model of Hepatic Energy Metabolism: Understanding Zonated Damage and Steatosis in NAFLD. PLoS Comput. Biol. 2016, 12, e1005105. [CrossRef]

63. Mechchate, H.; Es-Safi, I.; Bourhia, M.; Kyrylchuk, A.; El Moussaoui, A.; Conte, R.; Ullah, R.; Ezzeldin, E.; Mostafa, G.A.; Grafov, A.; et al. In-Vivo Antidiabetic Activity and In-Silico Mode of Action of LC/MS-MS Identified Flavonoids in Oleaster Leaves. Molecules 2020, 25, 5073. [CrossRef]

64. Su, C.; Yang, C.; Gong, M.; Ke, Y.; Yuan, P.; Wang, X.; Li, M.; Zheng, X.; Feng, W. Antidiabetic Activity and Potential Mechanism of Amentoflavone in Diabetic Mice. Molecules 2019, 24, 2184. [CrossRef]

65. Berman, H.M.; Battistuz, T.; Bhat, T.N.; Bluhm, W.F.; Bourne, P.E.; Burkhardt, K.; Feng, Z.; Gilliland, G.L.; Iype, L.; Jain, S.; et al. The Protein Data Bank. Acta Crystallogr. D Biol. Crystallogr. 2002, 58, 899-907. [CrossRef]

66. Trott, O.; Olson, A.J. AutoDock Vina: Improving the Speed and Accuracy of Docking with a New Scoring Function, Efficient Optimization, and Multithreading. J. Comput. Chem. 2010, 31, 455-461. [CrossRef]

67. Mechchate, H.; Es-safi, I.; Louba, A.; Alqahtani, A.S.; Nasr, F.A.; Noman, O.M.; Farooq, M.; Alharbi, M.S.; Alqahtani, A.; Bari, A.; et al. In Vitro Alpha-Amylase and Alpha-Glucosidase Inhibitory Activity and In Vivo Antidiabetic Activity of Withania Frutescens L. Foliar Extract. Molecules 2021, 26, 293. [CrossRef]

68. Pistia-Brueggeman, G.; Hollingsworth, R.I. A Preparation and Screening Strategy for Glycosidase Inhibitors. Tetrahedron 2001, 57, 8773-8778. [CrossRef] 